\title{
Protein kinase inhibitors for acute leukemia
}

\author{
Yuan Ling, Qing Xie, Zikang Zhang and Hua Zhang*
}

\begin{abstract}
Conventional treatments for acute leukemia include chemotherapy, radiation therapy, and intensive combined treatments (including bone marrow transplant or stem cell transplants). Novel treatment approaches are in active development. Recently, protein kinase inhibitors are on clinical trials and offer hope as new drugs for acute leukemia treatment. This review will provide a brief summary of the protein kinase inhibitors in clinical applications for acute leukemia treatment.
\end{abstract}

Keywords: Protein kinase inhibitor, Acute lymphocyte leukemia, Acute myeloid leukemia

\section{Background}

Acute leukemia is subdivided into acute myelocytic leukemia (AML) and acute lymphoblastic leukemia (ALL) $[1,2]$. AML accounts for about $90 \%$ of all acute leukemias in adults, and the cure rates are $35-40 \%$ in patients under 60 years old and $5-15 \%$ in those over 60 years old respectively [3]. The elderly always have poor prognosis with a median survival of 5-10 months. ALL is the most common subtype found in childhood with a peak incidence in $2-5$ years. Although more than $80 \%$ of children with ALL receive positive effect after treatments, there are only $20 \%-40 \%$ of adults ALL [4]. Philadelphia-positive acute lymphoblastic leukemia (Ph + ALL) has poor prognosis which is the most frequent genetic subtype of adult ALL and, in the elderly, Ph + ALL accounts for approximately $30 \%$ of cases $[5,6]$. To date, chemotherapy is still the main treatment strategy for leukemia. Although hematopoietic stem cell transplantation (HSCT) is also sometimes used as front-line therapy for patients with high-risk leukemia, usually, it is considered when induction chemotherapy fails or leukemia relapses $[7,8]$. Cancer cells typically evade the immune surveilence and have genetic heterogeneity with mutant targets [9]. Currently, emerging molecular targeted therapy is being used in clinic, such as inhibitors of FMS-like tyrosine kinase 3 (FLT3) and mammalian target of rapamycin (mTOR) in acute leukemia [10].

\footnotetext{
* Correspondence: huazhang@gdmu.edu.cn

Guangdong Provincial Key Laboratory of Medical Molecular Diagnostics, Institute of Laboratory Medicine, Guangdong Medical University, Dongguan 523808, China
}

(c) The Author(s). 2018 Open Access This article is distributed under the terms of the Creative Commons Attribution 4.0 International License (http://creativecommons.org/licenses/by/4.0/), which permits unrestricted use, distribution, and reproduction in any medium, provided you give appropriate credit to the original author(s) and the source, provide a link to the Creative Commons license, and indicate if changes were made. The Creative Commons Public Domain Dedication waiver (http://creativecommons.org/publicdomain/zero/1.0/) applies to the data made available in this article, unless otherwise stated.
Protein kinases are conventionally divided into five classes: protein tyrosine kinase, protein serine/threonine kinase, tryptophan protein kinase, histidine protein kinase and protein aspartyl/glutamoyl kinase. It has been proved that the abnormal activity of protein kinases is associated with many diseases like, inflammation immune system disease, and cancer including leukemia [12]. The main protein kinases particularly involve the phosphatidyl-inositol 3-kinase/v-akt murine thymoma viral oncogene homolog 1 (PI3K/AKT), mitogenactivated protein kinase/extracellular signal regulated kinase (MAPK/ERK), janus kinase signal transducer and activator of transcription (JAK-STAT) and signal transducer and activator of transcription 5 (STAT5) in AML observed to be aberrantly activated in a variety of malignancies, including pre-B-ALL, T cell ALL, and AML [13, 14]. Other targets have been reported, such as FLT3, Bruton's tyrosine kinase (BTK), mTOR, AKT, poly (ADP-ribose) polymerase (PARP), histone deacetylase (HDAC), etc. [15]. Thus, protein kinases have become new focus and PKIs have been developed as new anti- 
tumor drugs to disrupt the abnormal signal transduction in the therapy of acute leukemia.

As we all know the ABL-inhibitor imatinib became the first Food and Drug Administration (FDA)-approved small molecule protein kinase blocker. However, due to the emergence of many new mutation sites of protein kinase, the drug resistance to imatinib is more and more serious. Other pharmacological inhibitors including dasatinib and nilotinib, which are significantly more potent than imatinib and may overcome resistance have been developed. Imatinib and dasatinib, are registered for the treatment of Ph + ALL in adults [16]. On the other hand, imatinib and sunitinib reduce AML cell by blocking the activity of c-KIT pharmacologically [17, 18]. Many molecular changes are being studied the prognitic impact in acute leukemia. However, only FMS-like tyrosine kinase 3 internal tandem duplications (FLT3-ITDs), Nucleophosmin (NPM1), CCAAT/enhancer-binding protein- $\alpha(\mathrm{C} / \mathrm{EBP}-\alpha)$ and c-KIT have been currently incorporated in validated international risk stratification schema [19]. FLT3-ITDs is associated with worse prognosis in AML and several FLT3 inhibitors have undergone clinical trials [20]. Here, we summarized some PKIs are being used or under clinical evaluation at phase I, II and III clinical trials in acute leukemia (Table 1).

\section{Tyrosine protein kinase inhibitors \\ FLT3 inhibitors \\ Quizartinib (AC220)}

Quizartinib is a second-generation FLT3 inhibitor and selectively inhibits class III receptor tyrosine kinases including FLT3, stem cell factor receptor (SCFR), colonystimulating factor 1 receptor (CSF1R) and platelet derived growth factor receptors (PDGFRs), thus usually results in a better complete remissions in relapsed/ refractory $(\mathrm{r} / \mathrm{r})$ AML [21]. Other studies also showed that quizartinib can lead to favorable prognosis for the treatment of AML [22, 23].

\footnotetext{
Midostaurin

Midostaurin, a multi-target protein kinase inhibitor with anti-FLT3 activity which also combined with conventional induction and consolidation therapies, has been found to significantly prolong survival of FLT3mutated AML patients in the phase III clinical trial [15]. After successful Phase II clinical trials, midostaurin was approved by the FDA for the treatment of adult AML patients of FLT3 positive usually combining with chemotherapy or for companion diagnose to detect the FLT3 mutation in patients with AML [24]. Notably, the combination of midostaurin and chemotherapy for AML patients had 23\% improvement in overall survival (OS) [25].
}

\section{Sunitinib}

Sunitinib (SU11248), the first FLT3 inhibitor studied in the clinic, plays a role in inhibiting both tumor angiogenesis and tumor cell proliferation, and usually is used with cytarabine against AML cell lines with FL3-ITD mutation. However, sunitinib is a multi-targeted receptor tyrosine kinase (RTK) inhibitor and was proved to target platelet-derived growth factor (PDGF-Rs), vascular endothelial growth factor receptors (VEGFRs), and CD117 (cKIT) receptor tyrosine kinases except for FLT3 [26]. Sunitinib has been recommended as a second-line drug for patients resistant to imatinib due to c-KIT mutations or those who can not tolerate sunitinib [27].

\section{Lestaurtinib}

Lestaurtinib (rINN, codenamed CEP-701) is an inhibitor of the kinases FLT3, tropomyosin receptor kinase A/B/C (TrkA/B/C), Janus kinase 2 (JAK2) [28]. It is quite nonselective like inhibiting other tyrosine kinases like Janus kinase 2 (JAK2), and tropomycin receptor kinase (TRK) [29]. Previous studies have shown that lestaurtinib has the potential to promote apoptosis in FLT3-ITD leukemic cells [30]. Currently, lestaurtinib is being investigated to be combined with chemotherapy in infants and young children [31].

\section{Tandutinib (MLN518)}

Tandutinib, can supress the autophosphorylation of FLT3, c-KIT and PDGF (platelet-derived growth factor) receptor tyrosine kinases, thereby inhibiting cellular proliferation and inducing apoptosis in AML [32]. Tandutinib can improve the $C R$ rate to $90 \%$ in primarily diagonosed AML patients when used with daunorubicin and cytarabine [33].

\section{Gilteritinib (ASP2215)}

Gilteritinib, a pyrazinecarboxamide derivative, is on trial at phase I-II-III and a promising novel inhibitor of FLT3 inhibitors for its potential activity against all classes of FLT3-activating mutations [34]. In addition, a trial of gilteritinib as maintenance therapy for the first remission patients receiving HSCT are to be investigated [35].

\section{Crenolanib (PLX-3397)}

Crenolanib, the third generation agent, is an orally available drug that selectively and potently inhibits signaling of class III receptor tyrosine kinases (RTK) FLT3 and platelet-derived growth factor receptor $\alpha / \beta$ (PDGFR $\alpha /$ $\beta)$. Unlike most RTK inhibitors, crenolanib can be applied to the induction chemotherapy in AML [36].

\section{Bortezomib (PS-341)}

Bortezomib, a reversible $26 \mathrm{~S}$ proteasome inhibitor, can interfere with the transcription and induce the early 
Table 1 The therapeutic protein kinase inhibiors in acute leukemia

\begin{tabular}{|c|c|c|c|c|}
\hline Targets & Inhibitors & Comments & Main side effects & Phase \\
\hline \multirow[t]{8}{*}{ FLT3 } & Quizartinib & An anti-FLT3 TKI, was investigated in ALL or AML & Nausea, anemia, vomiting, etc & $\begin{array}{l}|-1|-|| \mid \\
{[70]}\end{array}$ \\
\hline & Midostaurin & $\begin{array}{l}\text { It is an oral multi-targeted kinase inhibitor to inihibit leukemia cells in- } \\
\text { cluding ALL and FLT3-positive AML }\end{array}$ & Diarhhoea, nausea, headache, etc. & $\begin{array}{l}|-||-||| \\
{[71]}\end{array}$ \\
\hline & Sunitinib & Sunitinib inhibits leukemia cells survival and angiogenesis & Cardiotoxic, dyspnea, etc. & II [72] \\
\hline & Lestaurtinib & $\begin{array}{l}\text { Lestaurtinib might inhibit the activity of FLT3 kinase and it is more } \\
\text { appropriate during intensive chemotherapy }\end{array}$ & Gastrointestinal reaction, etc. & $\begin{array}{l}|-||-||| \\
{[73]}\end{array}$ \\
\hline & Tandutinib & $\begin{array}{l}\text { It inhibits the FLT3 ITD-positive rather than the ITD-negative patients } \\
\text { with AML. }\end{array}$ & Bone pain, nausea, etc. & $|-||-|||$ \\
\hline & Gilteritinib & $\begin{array}{l}\text { Gilteritinib is a kind of favourable safety agent and is being on trial at } \\
120 \mathrm{mg} / \text { day }\end{array}$ & Diarrhea, etc. & $|-||-|||$ \\
\hline & Crenolanib & Crenolanib is a potential selective inhibitor of FLT3-ITDs and PDGFRa/ $\beta$ & Vomiting, headache, etc & $\|$ \\
\hline & Bortezomib & It is associated with apoptotic and autophagic cell death of AML & Gastro-intestinal, asthenia, etc & $\begin{array}{l}|-||-||| \\
{[74]}\end{array}$ \\
\hline \multirow[t]{2}{*}{ BTK } & Ibrutinib & $\begin{array}{l}\text { Although ibrutinib has its own unique toxicity, it usually causes fewer } \\
\text { infections }\end{array}$ & $\begin{array}{l}\text { Pneumonia, sinusitis, headache upper } \\
\text { respiratory tract infection, etc. }\end{array}$ & $\|$ \\
\hline & Acalabrutinib & It has received accelerated approval for the treatment of cell lymphoma & $\begin{array}{l}\text { Headache, diarrhea, weight gain skin rash, } \\
\text { severe diarrhea, etc. }\end{array}$ & $|-| \mid$ \\
\hline \multirow{4}{*}{$\begin{array}{l}\text { JAK- } \\
\text { STAT }\end{array}$} & Ruxolitinib & The JAK1/JAK2 inhibitor, is more effective against JAK-STAT pathway & Nausea, anemia, vomiting, ect. & III \\
\hline & $\begin{array}{l}\text { Pacritinib } \\
\text { (SB1518) }\end{array}$ & It is potent inhibitor FLT3-ITDs, JAK2, JAK2V617F in phase III development & Anemia, ect. & $\begin{array}{l}|-||-||| \\
{[75]}\end{array}$ \\
\hline & Everolimus & $\begin{array}{l}\text { Everolimus is combined with MK-2206, particularly important in the set- } \\
\text { ting of resistance to therapeutic drugs }\end{array}$ & $\begin{array}{l}\text { Cardiac failure, respiratory failure septic } \\
\text { shock, etc. }\end{array}$ & $\begin{array}{l}|-| \mid \\
{[76]}\end{array}$ \\
\hline & Temsirolimus & $\begin{array}{l}\text { Temsirolimus combines with etoposide, cyclophosphamide and } \\
\text { dexamethasone for relapsed pediatric ALL in adults }\end{array}$ & Nausea, etc. & $\begin{array}{l}|-1| \\
{[77]}\end{array}$ \\
\hline \multirow[t]{3}{*}{ mTOR } & Sirolimus & $\begin{array}{l}\text { Sirolimus is an mTOR inhibitor, but it has a similar suppressive effect on } \\
\text { the immune system }\end{array}$ & Abdominal pain, nausea, etc. & ॥ [78] \\
\hline & AZD8055 & $\begin{array}{l}\text { AZD8055 inhibits the phosphorylation of mTORC1 with p70S6K and 4E- } \\
\text { BP1 and downstream proteins }\end{array}$ & Anorexia, etc. & । \\
\hline & Ciclopirox & $\begin{array}{l}\text { Ciclopirox enhances the effect of the preclinical antileukemia while } \\
\text { irritation }\end{array}$ & Itching, blistering, swelling, etc. & । \\
\hline \multirow[t]{2}{*}{ MEK } & Pimasertib & It is a novel, selective, orally bioavailable MEK1/2 & Bleeding risk, etc. & $\|$ \\
\hline & GSK690693 & It inhibits apoptosis in sensitive ALL cell lines & Not clearly & । \\
\hline \multirow[t]{4}{*}{ AKT } & MK-2206 & $\begin{array}{l}\text { An orally inhibitor of the PI3KJAkt pathway which can inhibit tumor cell } \\
\text { proliferation }\end{array}$ & Fatigue, vomiting, anorexia, etc & $|-| \mid$ \\
\hline & T3151 & $\begin{array}{l}\text { The mutation of T315I occurs to patients even when second- and third- } \\
\text { genneration on trails }\end{array}$ & Nausea, swelling, rash, etc. & $\|-I\|$ \\
\hline & Gefitinib & A third-line agent and also is an EGFR inhibitor & Diarrhoea, vomiting, anorexia, etc. & ॥ [79] \\
\hline & Ponatinib & It is a multi-targeted tyrosine-kinase inhibitor often with hypertension & $\begin{array}{l}\text { Hypertension, rash, abdominal pain, } \\
\text { fatigue, etc. }\end{array}$ & $|-| \mid$ \\
\hline \multirow[t]{3}{*}{ Bcr-Abl } & Dasatinib & It also inhibits the Src kinase family & Anemia, diarrhea, swelling, rash, etc & $\|$ \\
\hline & ABL001 & $\begin{array}{l}\text { ABL001 is taken orally and the high does of it can be given safely to } \\
\text { patients }\end{array}$ & Not clearly & । \\
\hline & BEZ235 & $\begin{array}{l}\text { BEZ- } 235 \text { is a PI3K inhibitor. It also inhibits mTOR. It is being investigated } \\
\text { as a possible leukemia treatment. }\end{array}$ & Anemia, vomiting, etc & $|-| \mid$ \\
\hline \multirow[t]{2}{*}{ PI3K } & Idelalisib & Idelalisib is effective in leukemia patients who have p53 mutation & $\begin{array}{l}\text { Fever, fatigue, nausea, cough abdominal, } \\
\text { pain, rash, chills, etc. }\end{array}$ & $\begin{array}{l}\text { on } \\
\text { trial }\end{array}$ \\
\hline & PKI-587 & Gedatolisib is an agent targeting the PI3K/mTOR pathway & Nausea, etc. & 1 \\
\hline PLK1 & Volasertib & $\begin{array}{l}\text { It has been reported the volasertib inhibits PLK1 in both cancer and } \\
\text { normal cells }\end{array}$ & $\begin{array}{l}\text { Anaema, throm bocytopenia, nausea } \\
\text { febrile neutropenia, etc. }\end{array}$ & $|-| \mid$ \\
\hline
\end{tabular}


degradation of FLT3 internal tandem duplications (FLT3-ITD) through autophagy against ALL [37]. In addition, bortezomib can trigger the inhibition of MAPK/ERK, PI3K/AKT and STAT5 pathways in the AML [38, 39]. Evidence showed that bortezomib could potentiate the cytotoxic effects of combination chemotherapy in patients with leukemia.

\section{BTK inhibitors}

\section{Ibrutinib (Imbruvica)}

Ibrutinib inhibits pre-BCR+ B-cell by targeting Bruton's tyrosine kinase (BTK) and B lymphocyte kinase (BLK), while selectively targets FLT3-ITD in mutant FLT3positive in AML [40]. Clinical trials studies have demonstrated its tolerability in malignant B cells and has progressed into phase III trials. The combination treatment of ibrutinib with vincristine or dexamethasone demonstrated valid activity during the therapy of ALL [41].

\section{Acalabrutinib (ACP-196)}

Acalabrutinib, a second generation BTK inhibitor, has been shown to be better than ibrutinib for improved targeting specificity for BTK [42]. Large clinical samples and longer follow-up are still needed to ascertain these potential advantages.

\section{JAK-STAT inhibitors Ruxolitinib}

The JAK-STAT cell signaling pathway mainly regulates gene transcription. And the combination of ruxolitinib with nilotinib usually inhibits the proliferation of leukemia cells especially in Ph + ALL [43].

\section{Pacritinib (SB1518)}

Pacritinib (SB1518) was found to inhibit JAK2/FLT3 with a great potential for its less side effects in advanced myeloid malignancies, myelofibrosis and myeloproliferative neoplasms during phase I/II study [44].

\section{Other inhibitors}

\section{Gefitinib (ZD1839)}

Gefitinib is the third generation agent, and the first selective inhibitor of epidermal growth factor receptor (EGFR) tyrosine kinase domain. Although gefitinib can induce differentiation in AML cells, a phase II trial has shown that conventional use of gefitinib as a single agent for AML is not yet clear. Therefore, additional clinical trails are currently recruiting [45].

\section{Ponatinib}

Ponatinib (previously AP24534), the third-generation TKI, is an oral TKI drug developed for the treatment of T315I-positive $\mathrm{Ph}+\mathrm{ALL}$, however, it's appilcation may be limited for some ALL patients particularly with imatinib-resistance and multiple mutations [46].

\section{Protein serine/threonine kinase inhibitors mTOR inhibitors \\ Everolimus}

Everolimus can inhibit the mTORC1, and contributes to a high activation of the kinase AKT. Everolimus has important effect on the function of cell proliferation and the combination with azacitidine has shown promising clinical activity in AML [47].

\section{Temsirolimus}

Temsirolimus, a specific inhibitor of mTOR, interferes with cell growth. Currently, it is also found to be converted to sirolimus (rapamycin) in vivo [48]. Furthermore, the combination of temsirolimus with ibrutinib resulted in the cell growth reduction during the B-cell receptor pathway [49].

\section{Sirolimus}

Sirolimus, also known as rapamycin, inhibits activation of $\mathrm{T}$ cells and B cells. In vitro, it has also been found that sirolimus inhibits cell growth and even promotes cell death in B-precursor ALL $[50,51]$.

\section{AZD8055}

AZD8055 can inhibit mTORC1, mTORC2 and its downstream proteins through phosphorylation and markedly increase the survival of AML transplanted mice due to supress tumor growth [52]. Synergistic combinations of chemotherapy with low-dose AZD8055 could be more effective.

\section{Ciclopirox}

Ciclopirox, also an anti-fungal agent, is proved to be a novel specific mTOR kinase inhibitor and the combination with parthenolide which has been applied into preclinical antileukemia in AML and ciclopirox demonstrates greater availability against AML than treatment with either compound alone [53]. Besides ciclopirox could enhance the efficiency of compound parthenolide.

\section{MEK inhibitors}

Pimasertib, a MEK1/2 inhibitor, is efficient to target many hematologic malignancies including ALL and AML, however, the probability of clinical benefit and more effective clinical trials still remains to be warranted $[54,55]$.

\section{AKT inhibitors}

\section{GSK690693}

GSK690693 is a novel ATP-competitive Akt kinase inhibitor and selective for the Akt isoforms, while it also 
can inhibit additional members of the AGC kinase family [56].

\section{Mk-2206}

MK-2206 is another kind of oral inhibitor of Akt1/2/3 that promotes apoptosis and cell cycle arrest in AML [57]. During the trials of diffuse large B-cell lymphoma (DLBCL), MK-2206 significantly decreased p-AKT and downstream targets of AKT signaling [58].

\section{T315I}

T315I is an integrin-linked kinase (ILK) inhibitor, which downregulates protein kinase B (Akt) and p-Akt and decreases cell activity of AML [59]. The T315I is a unique mutation because of its resistance to the approved BCR$\mathrm{ABL}$ inhibitors. The BCR-ABL fusion gene is a driver oncogene in chronic myeloid leukemia and $30-50 \%$ of cases of adult ALL [60, 61]. Introduction of ABL1 kinase inhibitors like imatinib has markedly improved patient survival, but drug resistance still remains a challenge.

\section{Other inhibitor}

Alvocidib, also known as flavopiridol or HMR-1275, is a multi-serine threonine cyclin-dependent kinase inhibitor and mainly downregulates CDK7 and CDK9 to inhibit cMYC, cyclin D1, and MCL-1. Alvocidib has currently been examined in a phase II study for the treatment of intermediate- and high-risk AML combined with othet effective agents [62].

\section{Potential inhibitors in acute leukemia Volasertib}

Volasertib, also known as BI 6727 , is a small molecule inhibitor of the polo-like kinase 1 (PLK1) protein, and being developed as an anti-cancer agent with the potential combination therapy for those untreated patients who are ineligible for intensive induction therapy [63]. Volasertib is currently undergoing investigation in phase I and II trials and has not yet been licensed by the FDA.

\section{Dasatinib}

Dasatinib, former BMS 354825, is an orally available small-molecule multi-kinase inhibitor. It potently inhibits BCR-ABL and SRC-family kinases as well as PDGFR $\alpha / \beta, c-K I T$, and ephrin receptor kinase [64]. Dasatinib is approved for the treatment of Ph + ALL resistant or intolerant to imatinib.

\section{BEZ235}

BEZ235 is a dual PI3K/mTOR inhibitor and used in combination with dexamethasone in ALL. Inhibition of the PI3K/AKT/mTOR pathway with the dual PI3K/ mTOR inhibitor BEZ235 enhanced dexamethasone- induced anti-leukemic activity both in vitro and in vivo models of T-ALL $[65,66]$.

\section{Idelalisib}

Idelalisib is a promising treatment option for B-cell precursor acute lymphoblastic leukemia (BCP-ALL) patients with TCF3-PBX1 (E2A-PBX1), whereas other drugs could be useful depending on the genetic context of individual patients [67].

\section{PKI-587}

PKI-587 is a selective inhibitor to suppress T-ALL cells proliferation and colony formation through PI3K/mTOR pathway. It has been reported that PKI-587 could delay tumor progression and enhance the survival rate during the mouse xenograft models [68].

\section{ABL001}

ABL001, also named asciminib, could bind to the myristoyl pocket of ABL1 and induces the formation of kinase conformation. ABL001 is a potent and selective ABL1 inhibitor that is undergoing clinical development testing in patients with $\mathrm{CML}$ and $\mathrm{Ph}+$ acute lymphoblastic leukemia [69].

\section{Conclusions}

In summary, molecular targeted therapy has demonstrated impressive efficacy and the development of PKIs has promising impact on acute leukemia patients. With the rapid development of biological information technology, multiple new types of PKIs have been selected to treat acute leukemia patients separately or jointly with traditional treatments. However, there are still some challenges to overcome, such as the off-target effects and stability of the PKIs, the mutations of protein kinases, the best dose for individual patient, the drugresistance for PKIs, and the evoluted immune escape, etc. Thus, screening new targets and seeking novel effective PKIs are necessary and will provide more options for acute leukemia treatment.

\section{Abbreviations}

ALL: Acute lymphoblastic leukemia; AML: Acute myelocytic leukemia; BCPALL: B-cell precursor acute lymphoblastic leukemia; BLK: B lymphocyte kinase; BTK: Bruton's tyrosine kinase; C/EBP-a: CCAAT/enhancer-binding protein-a; CSF1R: Colony-stimulating factor 1 receptor; DLBCL: Iffuse large Bcell lymphoma; EGFR: Epidermal Growth Factor Receptor; FDA: Food and Drug Administration; FLT3: FMS-like tyrosine kinase 3; FLT3-ITD: FLT3 internal tandem duplications; FLT3-ITDs: FMS-like tyrosine kinase 3 internal tandem duplications; HDAC: Histone deacetylase; HSCT: Hematopoietic stem cell transplantation; ITD: Internal tandem duplication; JAK2: Janus kinase 2; JAKSTAT: Janus kinase signal transducer and activator of transcription; MAPK ERK: Mitogenactivated protein kinase/extracellular signal regulated kinase; mTOR: Mammalian target of rapamycin; NPM1: Nucleophosmin; OS: Overall survival; PARP: Poly (ADP-ribose) polymerase; PDGFR a/ $\beta$ : Platelet-derived growth factor receptor $\alpha / \beta$; PDGFRs: Platelet derived growth factor receptors; PDGF-Rs: Platelet-derived growth factor; Ph + ALL: Philadelphia-positive acute lymphoblastic leukemia; PI3K/AKT: Phosphatidyl-inositol 3-kinase/v-akt murine 
thymoma viral oncogene homolog 1; PKIs: Protein kinase inhibitors; PLK1: Polo-like kinase 1; RTK: Receptor tyrosine kinases; SCFR: Stem cell factor receptor; STAT5: Signal transducer and activator of transcription 5; TRK: Tropomycin receptor kinase; TrkA/B/C: Tropomyosin receptor kinase A/ B/C; VEGFRs: Vascular endothelial growth factor receptors

\section{Acknowledgements}

Not applicable.

\section{Funding}

This work was supported by National Natural Science Foundation of China (81300398), Natural Science Foundation of Guangdong Province, China (2015A030313528), and 2013 Sail Plan "the Introduction of the Shortage of Top-Notch Talent" Project (YueRenCaiBan [2014] 1).

\section{Availability of data and materials}

Not applicable.

\section{Authors' contributions}

All authors have contributed to write and revise the manuscripts. All authors have read and approved the final version.

\section{Ethics approval and consent to participate}

Not applicable.

\section{Consent for publication}

Not applicable.

\section{Competing interests}

The authors declare that they have no competing interests.

\section{Publisher's Note}

Springer Nature remains neutral with regard to jurisdictional claims in published maps and institutional affiliations.

Received: 18 December 2017 Accepted: 4 February 2018

Published online: 13 February 2018

\section{References}

1. Ma M, Wang X, Tang J, Xue H, Chen J, Pan C, et al. Early T-cell precursor leukemia: a subtype of high risk childhood acute lymphoblastic leukemia. Front Med. 2012;6(4):416-20.

2. Yang $X$, Wang J. Precision therapy for acute myeloid leukemia. J Hematol Oncol. 2018:11(1):3.

3. Dohner H, Weisdorf DJ, Bloomfield CD. Acute Myeloid Leukemia. N Engl J Med. 2015;373(12):1136-52

4. Zhang $\mathrm{E}, \mathrm{Xu} \mathrm{H}$. A new insight in chimeric antigen receptor-engineered $\mathrm{T}$ cells for cancer immunotherapy. J Hematol Oncol. 2017:10(1):1.

5. Granacher NCP, Berneman ZN, Schroyens W, Van de Velde ALR, Verlinden A, Gadisseur APA. Adult acute precursor B-cell lymphoblastic leukemia presenting as hypercalcemia and osteolytic bone lesions. Exp Hematol Oncol. 2017:6:9.

6. Chiaretti S, Foa R. How has the management of Ph+ acute lymphoblastic leukemia (ALL) changed over the years. Rinsho Ketsueki. 2016;57(10):2038-48

7. Yang J. SALL4 as a transcriptional and epigenetic regulator in normal and leukemic hematopoiesis. Biomark Res. 2018;6(1)

8. Testa U, Lo-Coco F. Targeting of leukemia-initiating cells in acute promyelocytic leukemia. Stem Cell Investig. 2015;2:8.

9. Vezzalini M, Mafficini A, Tomasello L, Lorenzetto E, Moratti E, Fiorini Z, et al. A new monoclonal antibody detects downregulation of protein tyrosine phosphatase receptor type gamma in chronic myeloid leukemia patients. J Hematol Oncol. 2017;10(1):129.

10. Wang AY, Weiner $H$, Green M, Chang H, Fulton $N$, Larson RA, et al. A phase I study of selinexor in combination with high-dose cytarabine and mitoxantrone for remission induction in patients with acute myeloid leukemia. J Hematol Oncol. 2018;11(1):4.

11. Dominguez-Berrocal L, Zhang X, Zini JM, Fominaya J, Rebollo A, Bravo J. Evaluation of caspase-9b and PP2Acalpha2 as potential biomarkers for chronic lymphocytic leukemia. Biomark Res. 2016;4:9.

12. Grant SK. Therapeutic protein kinase inhibitors. Cell Mol Life Sci. 2009;66(7): 1163-77.
13. Wang J, Liu X, Qiu Y, Shi Y, Cai J, Wang B, et al. Cell adhesion-mediated mitochondria transfer contributes to mesenchymal stem cell-induced chemoresistance on T cell acute lymphoblastic leukemia cells. J Hematol Oncol. 2018;11(1):11.

14. Lim SY, Lee JH, Welsh SJ, Ahn SB, Breen E, Khan A, et al. Evaluation of two high-throughput proteomic technologies for plasma biomarker discovery in immunotherapy-treated melanoma patients. Biomark Res. 2017;5:32.

15. Man LM, Morris AL, Keng M. New therapeutic strategies in acute lymphocytic leukemia. Curr Hematol Malig Rep. 2017;12(3):197-206.

16. Malagola M, Papayannidis C, Baccarani M. Tyrosine kinase inhibitors in Ph+ acute lymphoblastic leukaemia: facts and perspectives. Ann Hematol. 2016; 95(5):681-93.

17. An N, Cen B, Cai H, Song JH, Kraft A, Kang Y. Pim1 kinase regulates C-kit gene translation. Exp Hematol Oncol. 2016;5:31.

18. Saygin C, Carraway HE. Emerging therapies for acute myeloid leukemia. J Hematol Oncol. 2017;10(1):93.

19. Heidrich K, Thiede C, Schäfer-Eckart K, Schmitz N, Aulitzky WE, Krämer A, et al. Allogeneic hematopoietic cell transplantation in intermediate risk acute myeloid leukemia negative for FLT3-ITD, NPM1- or biallelic CEBPA mutations. Ann Oncol. 2017;28(11):2793-8.

20. Chen Y, Pan Y, Guo Y, Zhao W, Ho WT, Wang J, et al. Tyrosine kinase inhibitors targeting FLT3 in the treatment of acute myeloid leukemia. Stem Cell Investig. 2017:4:48.

21. An X, Liu J, Wang N, Wang D, Huang L, Zhang L, et al. AC220 and AraC cause differential inhibitory dynamics in patient-derived M5-AML with FLT3ITD and, thus, ultimately distinct therapeutic outcomes. Exp Hematol. 2017; 45:36-44.

22. Cortes JE, Kantarjian H, Foran JM, Ghirdaladze D, Zodelava M, Borthakur G, et al. Phase I study of quizartinib administered daily to patients with relapsed or refractory acute myeloid leukemia irrespective of FMS-like tyrosine kinase 3-internal tandem duplication status. J Clin Oncol. 2013; 31(29):3681-7.

23. Zhang Y, Xue D, Wang X, Lu M, Gao B, Qiao X. Screening of kinase inhibitors targeting BRAF for regulating autophagy based on kinase pathways. Mol Med Rep. 2014;9(1):83-90.

24. DeAngelo DJ, George TI, Linder A, Langford C, Perkins C, Ma J, et al. Efficacy and safety of midostaurin in patients with advanced systemic mastocytosis: 10-year median follow-up of a phase II trial. Leukemia. 2017; https://doi.org/ 10.1038/leu.2017.234.

25. Hassanein M, Almahayni MH, Ahmed SO, Gaballa S, Fakih El. R. FLT3 inhibitors for treating acute myeloid leukemia. Clin Lymphoma Myeloma Leuk. 2016;16(10):543-9.

26. Gan HK, Seruga B, Knox JJ. Sunitinib in solid tumors. Expert Opin Investig Drugs. 2009:18(6):821-34.

27. Fiedler W, Kayser S, Kebenko M, Janning M, Krauter J, Schittenhelm M, et al. A phase $1 / \|$ study of sunitinib and intensive chemotherapy in patients over 60 years of age with acute myeloid leukaemia and activating FLT3 mutations. Br J Haematol. 2015;169(5):694-700

28. Knapper S, Burnett AK, Littlewood T, Kell WJ, Agrawal S, Chopra R, et al. A phase 2 trial of the FLT3 inhibitor lestaurtinib (CEP701) as first-line treatment for older patients with acute myeloid leukemia not considered fit for intensive chemotherapy. Blood. 2006;108(10):3262-70.

29. Shabbir M, Stuart R. Lestaurtinib, a multitargeted tyrosine kinase inhibitor: from bench to bedside. Expert Opin Investig Drugs. 2010;19(3):427-36.

30. Wei G, Wang J, Huang H, Novel ZY. Immunotherapies for adult patients with Blineage acute lymphoblastic leukemia. J Hematol Oncol. 2017;10(1):150.

31. Al-Jamal HA, Mat JS, Hassan R, Johan MF. Enhancing SHP-1 expression with 5-azacytidine may inhibit STAT3 activation and confer sensitivity in lestaurtinib (CEP-701)-resistant FLT3-ITD positive acute myeloid leukemia. BMC Cancer. 2015:15:869.

32. Cheng Y, Paz K. Tandutinib, an oral, small-molecule inhibitor of FLT3 for the treatment of AML and other cancer indications. IDrugs. 2008;11(1):46-56.

33. Friedman $\mathrm{R}$. The molecular mechanism behind resistance of the kinase FLT3 to the inhibitor quizartinib. Proteins. 2017:85(11):2143-52.

34. Perl AE, Altman JK, Cortes J, Smith C, Litzow M, Baer MR, et al. Selective inhibition of FLT3 by gilteritinib in relapsed or refractory acute myeloid leukaemia: a multicentre, first-in-human, open-label, phase 1-2 study. Lancet Oncol. 2017:18(8):1061-75.

35. Hackl H, Astanina K, Molecular WR. Genetic alterations associated with therapy resistance and relapse of acute myeloid leukemia. J Hematol Oncol. 2017;10(1):51. 
36. Momparler RL. Optimization of cytarabine (ARA-C) therapy for acute myeloid leukemia. Exp Hematol Oncol. 2013;2:20.

37. Horton TM, Pati D, Plon SE, Thompson PA, Bomgaars LR, Adamson PC, et al. A phase 1 study of the proteasome inhibitor bortezomib in pediatric patients with refractory leukemia: a Children's oncology group study. Clin Cancer Res. 2007;13(5):1516-22.

38. Fan M, Li M, Gao L, Geng S, Wang J, Wang Y, et al. Chimeric antigen receptors for adoptive $T$ cell therapy in acute myeloid leukemia. J Hematol Oncol. 2017;10(1):151.

39. Horton TM, Gannavarapu A, Blaney SM, D'Argenio DZ, Plon SE, Berg SL. Bortezomib interactions with chemotherapy agents in acute leukemia in vitro. Cancer Chemother Pharmacol. 2006;58(1):13-23.

40. Collett L, Howard DR, Munir T, McParland L, Oughton JB, Rawstron AC, et al. Assessment of ibrutinib plus rituximab in front-line CLL (FLAIR trial): study protocol for a phase III randomised controlled trial. Trials. 2017;18(1):387.

41. Lichtenegger FS, Krupka C, Haubner S, Köhnke T, Recent SM. Developments in immunotherapy of acute myeloid leukemia. J Hematol Oncol. 2017;10(1): 142.

42. Wu J, Zhang M, Liu D. Acalabrutinib (ACP-196): a selective secondgeneration BTK inhibitor. J Hematol Oncol. 2016;9:21.

43. Kong Y, Wu YL, Song Y, Shi MM, Cao XN, Zhao HY, et al. Ruxolitinib/nilotinib cotreatment inhibits leukemia-propagating cells in Philadelphia chromosome-positive ALL. J Transl Med. 2017;15(1):184.

44. Verstovsek S, Odenike O, Singer JW, Granston T, Al-Fayoumi S, Phase DHJ. 1/ 2 study of pacritinib, a next generation JAK2/FLT3 inhibitor, in myelofibrosis or other myeloid malignancies. J Hematol Oncol. 2016;9(1):137.

45. Yadav M, Singh AK, Kumar H, Rao G, Chakravarti B, Gurjar A, et al. Epidermal growth factor receptor inhibitor cancer drug gefitinib modulates cell growth and differentiation of acute myeloid leukemia cells via histamine receptors. Biochim Biophys Acta. 2016;1860(10):2178-90.

46. Tojo A, Kyo T, Yamamoto K, Nakamae H, Takahashi N, Kobayashi Y, et al. Ponatinib in Japanese patients with Philadelphia chromosome-positive leukemia, a phase 1/2 study. Int J Hematol. 2017;106(3):385-97.

47. Tan P, Tiong IS, Fleming S, Pomilio G, Cummings N, Droogleever $M$, et al. The mTOR inhibitor everolimus in combination with azacitidine in patients with relapsed/refractory acute myeloid leukemia: a phase lb/ll study. Oncotarget. 2017:8(32):52269-80.

48. Qin L, Zhao R, Li P. Incorporation of functional elements enhances the antitumor capacity of CAR T cells. Exp Hematol Oncol. 2017;6:28.

49. Zoellner AK, Bayerl S, Hutter G, Zimmermann Y, Hiddemann W, Temsirolimus DM. Inhibits cell growth in combination with inhibitors of the B-cell receptor pathway. Leuk Lymphoma. 2015;56(12):3393-400.

50. Mathias MD, Ortiz MV, Magnan H, Ambati SR, Slotkin EK, Chou AJ, et al. A case report of concurrent embryonal rhabdomyosarcoma and diffuse large B-cell lymphoma in an adult without identifiable cancer predisposition. Biomark Res. 2017;5:7.

51. Brown VI, Fang J, Alcorn K, Barr R, Kim JM, Wasserman R, et al. Rapamycin is active against B-precursor leukemia in vitro and in vivo, an effect that is modulated by IL-7-mediated signaling. Proc Natl Acad Sci U S A. 2003; 100(25):15113-8.

52. Yates JWT, Holt SV, Logie A, Payne K, Woods K, Wilkinson RW, et al. A pharmacokinetic-pharmacodynamic model predicting tumour growth inhibition after intermittent administration with the mTOR kinase inhibitor AZD8055. Br J Pharmacol. 2017;174(16):2652-61.

53. Sen S, Hassane DC, Corbett C, Becker MW, Jordan CT, Guzman ML. Novel mTOR inhibitory activity of ciclopirox enhances parthenolide antileukemia activity. Exp Hematol. 2013;41(9):799-807.

54. Ravandi F, Pigneux A, DeAngelo DJ, Raffoux E, Delaunay J, Thomas X, et al. Clinical, pharmacokinetic and pharmacodynamic data for the MEK1/2 inhibitor pimasertib in patients with advanced hematologic malignancies. Blood Cancer J. 2015;5:e375.

55. Leonard JT, Raess PW, Dunlap J, Hayes-Lattin B, Tyner JW, Traer E. Functional and genetic screening of acute myeloid leukemia associated with mediastinal germ cell tumor identifies MEK inhibitor as an active clinical agent. J Hematol Oncol. 2016;9:31.

56. Brown JR. How I treat CLL patients with ibrutinib. Blood. 2018;131(4):379-86.

57. Wang J, Xu-Monette ZY, Jabbar KJ, Shen Q, Manyam GC, Tzankov A, et al. AKT Hyperactivation and the potential of AKT-targeted therapy in diffuse large B-cell lymphoma. Am J Pathol. 2017;187(8):1700-16.

58. Larsen JT, Shanafelt TD, Leis JF, LaPlant B, Call T, Pettinger A, et al. Akt inhibitor MK-2206 in combination with bendamustine and rituximab in relapsed or refractory chronic lymphocytic leukemia: results from the N1087 alliance study. Am J Hematol. 2017;92(8):759-63.

59. Xu P, Guo D, Shao X, Peng M, Chen B. Characteristics and mutation analysis of Ph-positive leukemia patients with T315I mutation receiving tyrosine kinase inhibitors. Onco Targets Ther. 2017;10:4731-8.

60. Diggs LP, Hsueh EC. Utility of PD-L1 immunohistochemistry assays for predicting PD-1/PD-L1 inhibitor response. Biomark Res. 2017;5:12.

61. Ghelli LDRA, lacobucci I, Martinelli G. The cell cycle checkpoint inhibitors in the treatment of leukemias. J Hematol Oncol. 2017;10(1):77.

62. LaCerte C, Ivaturi V, Gobburu J, Greer JM, Doyle LA, et al. Exposure-response analysis of Alvocidib (Flavopiridol) treatment by bolus or hybrid Administration in Newly Diagnosed or relapsed/refractory acute leukemia patients. Clin Cancer Res. 2017;23(14):3592-600.

63. Schnerch D, Schüler J, Follo M, Felthaus J, Wider D, Klingner K, et al. Proteasome inhibition enhances the efficacy of volasertib-induced mitotic arrest in AML in vitro and prolongs survival in vivo. Oncotarget. 2017;8(13): 21153-66.

64. Talpaz M, Shah NP, Kantarjian H, Donato N, Nicoll J, Paquette R, et al. Dasatinib in imatinib-resistant Philadelphia chromosome-positive leukemias. N Engl J Med. 2006;354(24):2531-41.

65. Deng $L$, Jiang $L$, Lin XH, Tseng KF, Liu Y, Zhang $X$, et al. The PI3K/mTOR dual inhibitor BEZ235 suppresses proliferation and migration and reverses multidrug resistance in acute myeloid leukemia. Acta Pharmacol Sin. 2017; 38(3):382-91.

66. Wei G, Ding L, Wang J, Hu Y, Huang H. Advances of CD19-directed chimeric antigen receptor-modified $T$ cells in refractory/relapsed acute lymphoblastic leukemia. Exp Hematol Oncol. 2017;6:10.

67. Coelho H, Badior M, Melo T. Sequential kinase inhibition (Idelalisib/lbrutinib) induces clinical remission in B-cell prolymphocytic leukemia harboring a 17p deletion. Case Rep Hematol. 2017;2017:8563218.

68. Neri LM, Cani A, Martelli AM, Simioni C, Junghanss C, Tabellini G, et al Targeting the PI3K/Akt/mTOR signaling pathway in B-precursor acute lymphoblastic leukemia and its therapeutic potential. Leukemia. 2014;28(4): 739-48

69. Wylie AA, Schoepfer J, Jahnke W, Cowan-Jacob SW, Loo A, Furet P, et al. The allosteric inhibitor ABL001 enables dual targeting of BCR-ABL1. Nature. 2017:543(7647):733-7.

70. Yamaura T, Nakatani T, Uda K, Ogura H, Shin W, Kurokawa N, et al. A novel irreversible FLT3 inhibitor, FF-10101, shows excellent efficacy against AML cells with FLT3 mutations. Blood. 2018;131(4):426-38.

71. Garcia JS, Percival ME. Midostaurin for the treatment of adult patients with newly diagnosed acute myeloid leukemia that is FLT3 mutation-positive. Drugs Today (Barc). 2017;53(10):531-43.

72. Cooper SL, Sandhu H, Hussain A, Mee C, Maddock H. Involvement of mitogen activated kinase kinase 7 intracellular signalling pathway in Sunitinib-induced cardiotoxicity. Toxicology. 2018;394:72-83.

73. Knapper S, Russell N, Gilkes A, Hills RK, Gale RE, Cavenagh JD, et al. A randomized assessment of adding the kinase inhibitor lestaurtinib to firstline chemotherapy for FLT3-mutated AML. Blood. 2017;129(9):1143-54.

74. YH M, Gaynon PS, Sposto R, van der Giessen J, Eckroth E, Malvar J, et al. Bortezomib with chemotherapy is highly active in advanced B-precursor acute lymphoblastic leukemia: Therapeutic Advances in Childhood Leukemia \&amp; Lymphoma (TACL) Study. Blood. 2012;120(2):285-90.

75. Verstovsek S, Komrokji RS. A comprehensive review of pacritinib in myelofibrosis. Future Oncol. 2015;11(20):2819-30.

76. Kolb EA, Gorlick R, Houghton PJ, Morton CL, Neale G, Keir ST, et al. Initial testing (stage 1) of AZD6244 (ARRY-142886) by the pediatric preclinical testing program. Pediatr Blood Cancer. 2010;55(4):668-77.

77. Rheingold SR, Tasian SK, Whitlock JA, Teachey DT, Borowitz MJ, Liu X, et al, A phase 1 trial of temsirolimus and intensive re-induction chemotherapy for 2nd or greater relapse of acute lymphoblastic leukaemia: a Children's oncology group study (ADVL1114). Br J Haematol. 2017;177(3):467-74.

78. Wasko JA, Westholder JS, Jacobson PA. Rifampin-sirolimus-voriconazole interaction in a hematopoietic cell transplant recipient. J Oncol Pharm Pract. 2017:23(1):75-9.

79. Weber C, Schreiber TB, Daub H. Dual phosphoproteomics and chemical proteomics analysis of erlotinib and gefitinib interference in acute myeloid leukemia cells. J Proteome. 2012;75(4):1343-56. 